\title{
Spline Truncated Nonparametric Regression Modeling for Maternal Mortality Rate in East Java
}

\author{
Fadhlul Rahim ${ }^{1}$, I Nyoman Budiantara ${ }^{2}$, and Erma Oktania Permatasari ${ }^{3}$ \\ Statistics Departement, Faculty of Mathematics, Computing and Data Science, \\ Institut Teknologi Sepuluh Nopember (ITS) \\ Jl. Arief Rahman Hakim, 60111 Surabaya Indonesia \\ e-mail: alumfr@gmail.com ${ }^{1}$, i_nyoman_b@statistika.its.ac.id ${ }^{2}$,erma@statistika.its.ac.id ${ }^{3}$,
}

\begin{abstract}
Maternal Mortality is the number of maternal deaths recorded during pregnancy, childbirth, and childbirth caused by pregnancy and childbirth, but not caused by accidents or falls. Since 2012 until 2015 it has been noted that maternal mortality rate has decreased from 359 to 305 maternal deaths per 100,000 live births. Despite the decline, the figure is still far from the target of the Sustainable Development Goals (SDGs) of 70 deaths per 100,000 live births. The analytical method used to determine the factors that influence maternal mortality rate is Nonparametric Spline Truncated Regression because the pattern of correlation between maternal mortality rate and each predictor variable obtained does not form a particular pattern. Based on the model obtained, the results are that all predictor variables have a significant effect on maternal mortality rate, namely the percentage of households with clean and healthy behavior, percentage of obstetric complications handling, percentage of pregnant women visits, percentage of households receiving cash assistance, and ratio of health centers and hospitals with a determination coefficient is 88,13 percent.
\end{abstract}

Keywords- Maternal Mortality, Spline Nonparametric Regression Truncated, SDGs

\section{INTRODUCTION}

$\mathrm{O}$ ne of the indicators that represent whether or not the health of the mother one is to look at maternal mortality rate in a given area. MMR is the number of maternal deaths were recorded during pregnancy, childbirth, and childbirth are caused by pregnancy, childbirth, and postpartum, but not caused by an accident or a fall which is the number of maternal deaths in every 100,000 live births.

In 2007 there was a decrease of MMR at 228 maternal deaths which had previously 390 maternal deaths since 1991. Based on the results of the Indonesian Demographic Health Survey (IDHS) in 2012 experienced a considerable increase, reaching 359 deaths. While MMR obtained from the InterCensus Survey in 2015 decreased, which was recorded at 305 maternal deaths per 100,000 live births [1]. Millennium Development Goals (MDGs) by 2015 for MMR is at 102 deaths per 100,000 live births. After the MDGs ended in 2015, a plan of sustainable development goals, called SDGs (Sustainable Development Goals) was formed as a change towards an improved development. If the MDG targets by $102 \mathrm{MMR}$, SDGs have a target to reduce MMR to 70 deaths per 100,000 live births. [2]

There are several studies that discuss the MMR conducted by Mutfi whose results showed that the percentage of households with percentage of households with clean and healthy behavior and the percentage of obstetric complications handling significantly influenced the number of maternal deaths in the regencies / city in East Java [3]. Research conducted by Smith showed that the percentage of pregnant women who carry K4 program, the percentage of pregnant women at high risk of complications are addressed, the percentage of pregnant women who get Fe3 tablet, and the percentage of births attended by conversant health workers gave significant effect towards MMR [4].

This study aims to determine the relationship between MMR each regencies / city in East Java in 2016 with the factors suspected to influence them is the percentage of household with percentage of households with clean and healthy behavior, the percentage of treatment of obstetric complications, the percentage of visits of pregnant women, the percentage of households receiving assistance cash, and the ratio of public health centers and hospitals. The application of East Java data is because East Java province is one of nine provinces that have the largest MMR in Indonesia based on Indonesian Demographic and Health Survey in 2013 [5]. One method that serves to determine the model of the relationship between the response variable and the predictor variable is the regression method. Regression method used is Spline Truncated nonparametric regression, because it is able to estimate the data that does not have a specific pattern and have a tendency to look for the estimates of data from the patterns that are not randomly formed. In this study, the pattern acquired from the correlation between the MMR data with each of the predictor variables do not form a specific pattern, therefore that the method used apoppriate. It is expected that with this research will be able to provide policy recommendations to the government in order to suppress maternal mortality rate in East Java province.

\section{LITERATURE REVIEW}

\section{A. Nonparametric Regression}

Nonparametric regression is one method used to determine the pattern of the relationship between the response and predictor variables where the function of regression curve is unknown. Nonparametric regression model [6] in general can be shown in Equation (1) as follows.

$$
y_{i}=f\left(x_{i}\right)+\varepsilon_{i}, \quad i=1,2, \ldots, n
$$

Nonparametric approach is used to estimate the regression curve because the models are not determined in advance as in the parametric regression. In view of the nonparametric regression of data expected to find the regression curve without being influenced by the subjective factor of researchers.

\section{B. Spline Truncated Nonparametric Regression}

One of the nonparametric regression model used is the Spline. Spline is a segmented polynomial that has the flexibility 
properties. Spline depends on the point of knots. Knots point is a joint fusion point where a pattern of behavior changes from a function at different intervals [7]. In general, the function of $G$ in the space of order $m$ at the point Spline knots $\mathrm{k} 1, \mathrm{k} 2, \ldots, \mathrm{kj}$ is any function that can be expressed in Equation (2) as follows.

$$
G\left(x_{i}\right)=\sum_{j=0}^{m} \beta_{j} x_{i}^{j}+\sum_{k=1}^{J} \beta_{k+m}\left(x_{i}-K_{k}\right)_{+}^{m}
$$

with,

$$
\left(x_{i}-K_{k}\right)_{+}^{m}=\left\{\begin{array}{cc}
\left(x_{i}-K_{k}\right)^{m}, & \mathrm{x}_{i} \geq K_{k} \\
0 & , \mathrm{x}_{i}<K_{k}
\end{array}\right.
$$

$B$ is parameter models with $m$ being the order of Spline [8].

\section{Optimum Knot Point Selection}

The best Spline estimator is obtained by using optimal knot point. Knot point is the joint point where there is a change of behavior patterns or curves function. Optimal knot point can be obtained using methods Generalied Cross Validation (GCV) [7]. GCV method has asymptotically optimal properties, which means it can be used for large samples. The asymptotically optimal trait not shared by other methods, such as Cross Validation (CV) [9]. Additionally, it has the invariant nature of the transformation, which means the data can be transformed if the residual assumption are not fulfilled. Best spline regression model derived from optimal knots point to see the smallest GCV value. GCV method can be written as follows [6],

$$
G C V(k)=\frac{\operatorname{MSE}(k)}{\left[n^{-1} \operatorname{trace}(\mathbf{I}-\mathbf{A})\right]^{2}}
$$

where $\mathrm{I}$ is the identity matrix, $\mathrm{n}$ is a lot of observation, $k=\left(k_{1}, k_{2}, \ldots, k_{r}\right)$ are points of knots, and

$$
\operatorname{MSE}(k)=n^{-1} \sum_{i=1}^{n}\left(y_{i}-\hat{f}\left(x_{i}\right)\right)^{2}
$$

\section{Maternal Mortality}

MMR is the number of maternal deaths were recorded during pregnancy, childbirth, and postpartum hildbirth are caused by pregnancy, childbirth, postpartum and or its management, but not caused by an accident or a fall which is the number of maternal deaths in every 100,000 births. Factors that could cause the death of the mother during pregnancy is maternal age, parity, health services, antenatal care, helper, facilities and infrastructure, as well as social, economic, and cultural [10].

\section{RESEARCH METHODS}

\section{A. Data source}

The data used in this research is secondary data obtained from the East Java Provincial Health Profile 2016 published by the East Java Health Departement and there is a secondary data obtained from the Central Bureau of Statistics. The research unit with the regencies / cities in East Java with a number of observations were 38 consisting of 9 cities and 29 counties in 2016.

\section{B. Research variable} below.

The variables used in this study is shown in Table 1
Table 1.Research variable

\begin{tabular}{cl}
\hline variables & \multicolumn{1}{c}{ variable name } \\
\hline$y$ & Maternal Mortality \\
$x 1$ & $\begin{array}{l}\text { Percentage of household with percentage of } \\
\text { households with clean and healthy behavior }\end{array}$ \\
$x 2$ & Percentage of obstetric complications handling \\
$x 3$ & Percentage of pregnant women visit \\
$x 4$ & Percentage of households receiving cash \\
& assistance \\
$x 5$ & The ratio of public health centers and hospitals \\
\hline
\end{tabular}

\section{Step Research}

The method used in this study is Truncated Spline Nonparametric Regression. Here are the steps of analysis used in this research according to the research objectives.

1. Analyzing the characteristics of MMR in regencies / cities in East Java.

i. MMR describe each Regency / city in East Java and the factors suspected of influencing it.

ii. Creating a scatter plot between the response variable with each of the predictor variables to determine the pattern of relationships that occur.

2. MMR model in Regencys / cities in East Java by using spline Nonparametric Regression Truncated method

i. Choosing the optimal knots point based on the value of the minimum GCV.

ii. Getting the best spline regression model with the point of optimal knots.

iii. To test the significance of parameters simultaneously and partially.

iv. To test the assumption of residual identical, independent and normally distributed (IIDN) of spline regression model.

v. Creating a model interpretation and draw conclusions.

\section{RESULTS AND DISCUSSION}

\section{A. MMR Data Characteristics and Factors Affecting}

Data MMR in East Java province in 2016 and the factors influencing it allegedly will be described using the mean, variance, minimum and maximum values. Here is the MMR data characteristics and factors that influence allegedly shown in Table 2.

Table 2. MMR Characteristics and Factors Affecting Suspected

\begin{tabular}{ccccc}
\hline variables & mean & variance & Minimum & Maximum \\
\hline Y & 99.86 & 1832.97 & 38.37 & 236.18 \\
X1 & 49.64 & 218.41 & 19.4 & 75.1 \\
X2 & 96.04 & 238.11 & 62.1 & 129.5 \\
X3 & 88.911 & 24.889 & 78.9 & 98.5 \\
X4 & 2.342 & 6.118 & 0 & 11.78 \\
X5 & 7.812 & 9.213 & 4.53 & 18.69 \\
\hline
\end{tabular}

Based on Table 2, Y is a variable MMR in East Java in 2016 where the average maternal mortality rate in East Java province in 2016 amounted to 99.86 maternal deaths per 100,000 live births in every regencies / city with a large variance value, means that the county / city there are certain high maternal mortality rate and low. It can be seen from the value of the minimum and maximum MMR in East Java, which is the lowest MMR is the Madiun City, while a highest MMR is Blitar City. 


\section{B. Spline Truncated Nonparametric Regression Model}

Truncated spline nonparametric regression model with point five knots with the nonparametric components can generally be written as follows.

$$
\begin{aligned}
y_{i}= & \beta_{0}+f\left(x_{i 1}\right)+f\left(x_{i 2}\right)+f\left(x_{i 3}\right)+f\left(x_{i 4}\right)+f\left(x_{i 5}\right)+\varepsilon_{i} \\
= & \beta_{0}+\sum_{j=1}^{p} \beta_{j} x_{i 1}^{j}+\sum_{k=1}^{r} \beta_{p+k}\left(x_{i 1}-K_{k}\right)_{+}^{p}+\sum_{j=1}^{p} \beta_{j} x_{i 2}^{j}+ \\
& \sum_{k=1}^{r} \beta_{p+k}\left(x_{i 2}-K_{k}\right)_{+}^{p}+\sum_{j=1}^{p} \beta_{j} x_{i 3}^{j}+\sum_{k=1}^{r} \beta_{p+k}\left(x_{i 3}-K_{k}\right)_{+}^{p}+ \\
& \sum_{j=1}^{p} \beta_{j} x_{i 4}^{j}+\sum_{k=1}^{r} \beta_{p+k}\left(x_{i 4}-K_{k}\right)_{+}^{p}+\sum_{j=1}^{p} \beta_{j} x_{i 5}^{j}+\sum_{k=1}^{r} \beta_{p+k}\left(x_{i 5}-K_{k}\right)_{+}^{p}+\varepsilon_{i}
\end{aligned}
$$

\section{Optimum Knot Point Selection}

Further after obtaining value knots with GCV most optimum value for each predictor variable is to compare the value of the GCV of each spline nonparametric regression model to determine the best knots. Here are the smallest GCV value of each knot point results shown in Table 3.

Table 3. Smallest GCV value of Modeling Each Knot

\begin{tabular}{ccc}
\hline Total Knot & GCV & R-Square \\
\hline 1 Point Knot & 1641.07 & 53.58 \\
2 Point Knot & 1641.07 & 53.58 \\
3 Point Knot & 1013.23 & 88.64 \\
Combination Knot (3 3 3 2 3) & $\mathbf{8 4 7 . 4 0}$ & $\mathbf{8 8 . 1 3}$ \\
\hline
\end{tabular}

GCV value of each model of each knot in Table 3 shows that the value of the minimum GCV is a model with a combination of spline knots. The combination of knots optimum point is three knots point to a variable percentage of household with percentage of households with clean and healthy behavior, the percentage of obstetric complications handling, pregnant women visit, and a variable ratio of health centers and hospitals, as well as two point knots for variable households receiving cash assistance. It can be concluded that the spline nonparametric regression model with a combination of knots by the number of model parameters as many as 20 parameters.

\section{Parameter Estimation}

Based on the results of the calculation to obtain the minimum GCV value, the model is best spline spline knots combination. The combination of the knot point is for the variables $\mathrm{x} 1, \mathrm{x} 2, \mathrm{x} 3$, and $\mathrm{x} 5$ is a three-point knots, while the $\mathrm{X} 4$ is two point knots. Thus, the parameter estimates for nonparametric regression models with a combination of knots using OLS method is as follows.

$$
\begin{aligned}
\hat{y}_{i}= & 2005,068-13,893 x_{i 1}+87,573\left(x_{i 1}-33,04\right)_{+}- \\
& 115,974\left(x_{i 1}-34,18\right)_{+}+43,329\left(x_{i 1}-35,31\right)_{+}+3,183 x_{i 2}+ \\
& 203,151\left(x_{i 2}-78,61\right)_{+}-425,818\left(x_{i 2}-79,98\right)_{+}+ \\
& 219,063\left(x_{i 2}-81,36\right)_{+}-21,155 x_{i 3}+227,846\left(x_{i 3}-83,7\right)_{+}- \\
& 178,720\left(x_{i 3}-84,1\right)_{+}-33,717\left(x_{i 3}-84,5\right)_{+}-1,063 x_{i 4}- \\
& 51,805\left(x_{i 4}-6,25\right)_{+}-10^{-11}\left(x_{i 4}-11,78\right)_{+}-5,522 x_{i 5}+ \\
& 378,088\left(x_{i 5}-8\right)_{+}-715,129\left(x_{i 5}-8,29\right)_{+}+ \\
& 340,972\left(x_{i 5}-8,58\right)_{+}
\end{aligned}
$$

The coefficient of determination obtained from the truncated spline nonparametric regression model is 88.1299 percent. This value indicates that the variable Maternal
Mortality Rate (MMR) in East Java province in 2016 can be explained by five predictor variables of 88.1299 percent, while the remaining 11.8701 percent can be explained by other variables that are not included in the model.

\section{E. Regression Parameter Testing}

There are two tests used parameters, namely the simultaneous test and partial test. The test results simultaneously displayed in Table 4 with the following hypotheses.

$H_{0}: \beta_{1}=\ldots=\beta_{19}=0$

$H_{l}:$ At least there is one $\beta \mathrm{j} \neq 0, \mathrm{j}=1,2, \ldots, 19$

Table 4. Analysis of Variance

\begin{tabular}{cccccc}
$\begin{array}{c}\text { source of } \\
\text { Variation }\end{array}$ & $\boldsymbol{d} \boldsymbol{f}$ & $\boldsymbol{S S}$ & $\boldsymbol{M S}$ & $\boldsymbol{F}$ & $\boldsymbol{P}$-Value \\
\hline Regression & 19 & 59770.1 & 3145.795 & 7.03378 & $6,2289 \times 10-$ \\
Error & 18 & 8050.339 & 447.241 & & 5 \\
Total & 37 & 67820.43 & & & \\
\hline
\end{tabular}

\begin{tabular}{|c|c|c|c|c|}
\hline variables & Parameter & estimator & $t$ & P-value \\
\hline Constant & $\beta_{0}$ & 2005.068 & 2.9254 & 0.009035 \\
\hline \multirow{4}{*}{$x_{1}$} & $\beta_{1}$ & -13.893 & -4.3716 & 0.000368 \\
\hline & $\beta_{2}$ & 87.573 & 2.7900 & 0.012092 \\
\hline & $\beta_{3}$ & -115.974 & -2.1728 & 0.043394 \\
\hline & $\beta_{4}$ & 43.329 & 1.5805 & 0.131411 \\
\hline \multirow{4}{*}{$x_{2}$} & $\beta_{5}$ & 3.183 & .9918 & 0.334427 \\
\hline & $\beta_{6}$ & 203.151 & 3.2895 & 0.004074 \\
\hline & $\beta_{7}$ & -425.818 & -3.6279 & 0.001924 \\
\hline & $\beta_{8}$ & 219.063 & 3.7698 & 0.001402 \\
\hline \multirow{4}{*}{$x_{3}$} & $\beta_{9}$ & -21.155 & -2.2843 & 0.034710 \\
\hline & $\beta_{10}$ & 227.846 & 1.3885 & 0.181933 \\
\hline & $\beta_{11}$ & -178.720 & -0.6485 & 0.524815 \\
\hline & $\beta_{12}$ & -33.717 & -0.2672 & 0.792329 \\
\hline \multirow{4}{*}{$x_{3}$} & $\beta_{9}$ & -21.155 & -2.2843 & 0.034710 \\
\hline & $\beta_{10}$ & 227.846 & 1.3885 & 0.181933 \\
\hline & $\beta_{11}$ & -178.720 & -0.6485 & 0.524815 \\
\hline & $\beta_{12}$ & -33.717 & -0.2672 & 0.792329 \\
\hline \multirow{3}{*}{$x_{4}$} & $\beta_{13}$ & -1.063 & -0.4346 & 0.668977 \\
\hline & $\beta_{14}$ & -51.805 & -3.7087 & 0.001607 \\
\hline & $\beta_{15}$ & $-10-11$ & -14.040 & $\begin{array}{c}3,87 \times 10- \\
11\end{array}$ \\
\hline \multirow{4}{*}{$x_{5}$} & $\beta_{16}$ & -5.522 & -0.8065 & 0.430469 \\
\hline & $\beta_{17}$ & 378.088 & 2.8035 & 0.011749 \\
\hline & $\beta_{18}$ & -715.129 & -2.8063 & 0.011676 \\
\hline & $\beta_{19}$ & 340.972 & 2.6277 & 0.017073 \\
\hline
\end{tabular}

Based on Table $4 F$ test statistic values obtained by 7.03378 . $\mathrm{F}$ table value for degrees of freedom $\mathrm{v} 1$ and $\mathrm{v} 2=19=18$ with $\alpha=0.05$ is 2.182 . Then the statistic value $F>\mathrm{F} 0,05$; (19.18) so that it can be concluded Reject H0, which means there is a minimum of predictor variables which has significant impact on the model. after the test is done simultaneously, further individual test results can be seen in Table 5 with the following hypothesis.

$H_{0}: \beta_{j}=0$

$H_{l}: \beta_{j} \neq 0, \mathrm{j}=1,2, \ldots, 19$

Table 5. Significance Testing Results Parameter Individually

Based on test results in partial or individual parameters using the $t$ test statistic of all the variables that go into the model a significant effect. There are seven parameters that are not significant because the $p$-value is higher than the value of $\alpha$, which is $\beta 4, \beta 5, \beta 10, \beta 11, \beta 12, \beta 13$, and $\beta 16$. Meanwhile, 13 other parameters have been significant for $p$-value less than the 
value $\alpha$, namely $\beta 0, \beta 1, \beta 2, \beta 3, \beta 6, \beta 7, \beta 8, \beta 9, \beta 14, \beta 15, \beta 17$, $\beta 18, \beta 19$. Although there is not a significant parameter, all five predictor variables remained significant effect on the Maternal Mortality Rate (MMR) due to any predictor variables are significant parameters.

\section{F. Residual Assumptions Testing}

Residual assumptions that must be fulfilled for a model of the nonparametric regression residuals spline is assuming identical, independent and normally distributed. identical residuals assumptions test using the statistic test. Assumption testing of independent residuals using the Durbin-Watson test. While testing the residual assuming normal distribution using the Kolmogorov -. Glejser statistic test test results can be seen in Table 6 with the following hypotheses.

$H_{0}: \sigma_{1}^{2}=\sigma_{2}^{2}=\ldots=\sigma_{n}^{2}=\sigma^{2}$
$H_{1}: \sigma_{i}^{2} \neq \sigma^{2} ; i=1,2, \ldots, 38$

Table 6 Test Result Test Statistics Glejser

\begin{tabular}{cccccc}
\hline Source & Df & SS & MS & Fhit & P-value \\
\hline Regression & 19 & 1654.187 & 87.0625 & 1,378 & 0250 \\
Error & 18 & 1137.384 & 63188 & & \\
Total & 37 & 27571 & & & \\
\hline
\end{tabular}

In the test results identical to the values obtained using the test Glejser $\mathrm{Fc}_{\mathrm{ount}} 1.378$. Value $F 0,05$; (19.18) of 2.4134, where the value is higher than the value of $F$, then the decision is Fail Reject $\mathrm{H}_{0}$, which means heteroscedasticity is not happening in the model, so that identical residual assumptions have been fulfilled. Durbin-Watson test results to determine whether there is autocorrelation between residuals with the following hypotheses.

$\mathrm{H}_{0}: \rho=0$ (autocorrelation does not happen)

$\mathrm{H}_{0}: \rho \neq 0$ (autocorrelation does happen)

$$
d=\frac{\sum_{i=1}^{n}\left(e_{i}-e_{i-1}\right)^{2}}{\sum_{i=1}^{n} e_{i}^{2}}=\frac{19673,958}{7999,256}=2,431445
$$

From the analysis of the Durbin-Watson test are obtained where $e$ is the residual of data can be seen that the DurbinWatson value obtained is equal to 2.431445 . Residual can be said there is autocorrelation when the value of $d(d=2.431445)$ is lower than the value $d_{L}\left(d_{L}=1.2614\right)$ or the value of $d$ is lower than the value of $d_{u}\left(d_{u}=1.7223\right)$. Based on the results obtained, the value of $\mathrm{d}$ is higher than the value of $d_{L}$ and value $d$ is also lower than the value $d u$, so the decision is Fail Reject $\mathrm{H}_{0}$. The conclusion is already evident that the independent or not there is residual autocorrelation. Kolmogorov-Smirnov test results can be seen in Picture 1 with the following hypotheses.

$H_{0}: F_{n}(\varepsilon)=F_{0}(\varepsilon)$

$H_{0}: F_{n}(\varepsilon) \neq F_{0}(\varepsilon)$

To determine residual normal distribution can be done by comparing the value of the Kolmogorov-Smirnov Test Kolmogorov value, amounting to 0.215 . It was found that the value of the Kolmogorov-Smirnov 0.119. The result is a smaller value than the value KS Kolmogorov Test, meaning the residual residuals have a normal distribution.

\section{G. Model Interpretation}

Based on nonparametric models obtained previously, here is a model and interpretation of the truncated spline nonparametric regression model best on Maternal Mortality in East Java with five variables were significant predictors.

$$
\begin{aligned}
\hat{y}_{i}= & 2005,068-13,893 x_{i 1}+87,573\left(x_{i 1}-33,04\right)_{+}- \\
& 115,974\left(x_{i 1}-34,18\right)_{+}+43,329\left(x_{i 1}-35,31\right)_{+}+3,183 x_{i 2}+ \\
& 203,151\left(x_{i 2}-78,61\right)_{+}-425,818\left(x_{i 2}-79,98\right)_{+}+ \\
& 219,063\left(x_{i 2}-81,36\right)_{+}-21,155 x_{i 3}+227,846\left(x_{i 3}-83,7\right)_{+}- \\
& 178,720\left(x_{i 3}-84,1\right)_{+}-33,717\left(x_{i 3}-84,5\right)_{+}-1,063 x_{i 4}- \\
& 51,805\left(x_{i 4}-6,25\right)_{+}-10^{-11}\left(x_{i 4}-11,78\right)_{+}-5,522 x_{i 5}+ \\
& 378,088\left(x_{i 5}-8\right)_{+}-715,129\left(x_{i 5}-8,29\right)_{+}+ \\
& 340,972\left(x_{i 5}-8,58\right)_{+}
\end{aligned}
$$

1. Assuming constant predictor variables other than $x_{1}$, the regression equation of a variable percentage of household with percentage of households with clean and healthy behavior and a variable percentage of household with percentage of households with clean and healthy behavior belonging to the nonparametric component, so that the model can be written as follows.

$$
\hat{y}= \begin{cases}2005,068-13,893 x_{1} & ; x_{1}<33,04 \\ -888,344+73,68 x_{1} & ; 33,04 \leq x_{1}<34,04 \\ 5969,059-129,867 x_{1} & ; 34,04 \leq x_{1}<35,31 \\ 475,121+29,436 x_{1} & ; x_{1} \geq 35,31\end{cases}
$$

The percentage of households on the condition of percentage of households with clean and healthy behavior less than 33.04 if the addition of 1 unit of the MMR will be decreased by 13.893 per 100,000 live births. Regencies / cities included in the category of percentage of household with percentage of households with clean and healthy behavior less than 33.04 is Malang Regency, Bondowoso Regency, Situbondo Regency, Probolinggo Regency, and Batu City.

The percentage of households on the condition of percentage of households with clean and healthy behavior in between 33.04 and 34.04 in the event increments of 1 unit of the MMR will be an increase of 73.68 per 100,000 live births. Regencies / cities included in the category of percentage of household with percentage of households with clean and healthy behavior in between 33.04 and 34.04 is Trenggalek Regency.

The percentage of households on the condition of percentage of households with clean and healthy behavior in between 34.04 and 35.31 in the event increments of 1 unit of the MMR will be decreased by 129.687 per 100,000 live births. Regencies / cities included in the category of percentage of household with percentage of households with clean and healthy behavior in between 34.04 and 35.31 is Lumajang Regency, Sampang Regency, and Pamekasan Regency.

The percentage of households on the condition of percentage of households with clean and healthy behavior is higher than 35.31 if the addition of 1 unit of the MMR will increase by 29.436 per 100,000 live births. Regencies / cities included in the category of percentage of household 
percentage of households with clean and healthy behavior higher than 35.31 is Pacitan Regency, Ponorogo Regency, Tulungagung Regency, Blitar Regency, Kediri Regency, Jember Regency, Banyuwangi Regency, Pasuruan Regency, Gresik Regency, Mojokerto Regency, Jombang Regency, Nganjuk Regency, Madiun Regency, Magetan Regency, Ngawi Regency, Bojonegoro Regency, Tuban Regency, Lamongan Regency, Sidoarjo Regency, Regency Bangkalan, Sumenep Regency, Kediri City, Blitar City, Malang City, Probolinggo City, Pasuruan City, Mojokerto City, Madiun City and Surabaya City.

2. Assuming constant predictor variables other than $x_{2}$, then the regression equation of a variable percentage of obstetric complications confectionary and variable percentages handling obstetric complications included into nonparametric component, so that the model can be written as follows.

$$
\hat{y}= \begin{cases}2005,068+3,183 x_{2} & ; x_{2}<78,61 \\ -13964,632+206,334 x_{2} & ; 78,61 \leq x_{2}<79,98 \\ -32051,855-422,635 x_{2} & ; 79,98 \leq x_{2}<81,36 \\ -15824,469+222,246 & ; x_{2} \geq 81,36\end{cases}
$$

On the condition of obstetric complications handling percentage of less than 78.61 if the addition of 1 unit of the MMR will be an increase of 3.183 per 100,000 live births. Regencies / cities included in the category of percentage of treatment of obstetric complications is less than 78.61 Sidoarjo Regency, Bangkalan Regency, and Pasuruan Regency.

On the condition of obstetric complications in handling percentage between 78.61 and 79.98 in the event increments of 1 unit of the MMR will increase by 206.334 per 100,000 live births. However, no regency / city are included in the category of percentage handling obstetric complications between 78.61 and 79.98.

On the condition of obstetric complications in handling percentage between 79.98 and 81.36 in the event increments of 1 unit of the MMR will be decreased by 422.635 per 100,000 live births. Regencies / cities included in the category of percentage handling obstetric complications between 79.98 and 81.36 is Lamongan Regency, Blitar City and Probolinggo City.

On the condition of obstetric complications handling percentage is greater than 81.36 if the addition of 1 unit of the MMR will increase by 222.246 per 100,000 live births. Regencys / cities included in the category of percentage of treatment of obstetric complications is less than 81.36 Pacitan Regency, Ponorogo Regency, Trenggalek Regency, Tulungagung Regency, Blitar Regency, Kediri Regency, Malang Regency, Jember Regency, Banyuwangi Regency, Bondowoso Regency, Situbondo Regency, Probolinggo Regency,. Pasuruan Regency, Mojokerto Regency, Jombang Regency, Nganjuk Regency, Madiun Regency, Magetan Regency, Ngawi Regency, Bojonegoro Regency, Tuban Regency, Gresik Regency, Sampang Regency, Pamekasan Regency, Sumenep Regency, Kediri City, Malang City, Mojokerto City, Madiun, Surabaya, and Batu City.
3. Assuming constant predictor variables besides $x_{3}$, then the regression equation of a variable percentage of pregnant women visit and a variable percentage of visits of pregnant women included in the nonparametric component, so that the model can be written as follows.

$$
\hat{y}= \begin{cases}2005,068-21,115 x_{3} & ; x_{3}<83,7 \\ -17065,642+206,691 x_{3} & ; 83,7 \leq x_{3}<84,1 \\ 17035,42-199,875 x_{3} & ; 84,1 \leq x_{3}<84,5 \\ 4854,154-54,872 x_{3} & ; x_{3} \geq 84,5\end{cases}
$$

On the condition of the percentage of pregnant women who visit less than 83.7 if it occurs in increments of 1 unit of the MMR will be decreased by 21.115 per 100,000 live births. Regenciess / cities included in the category of the percentage of pregnant women visit of less than 83.7 are Pacitan Regency, Jember Regency, Bondowoso Regency, Probolinggo Regency. Nganjuk Regency, and Regency Bangkalan.

On the condition of pregnant women the percentage of visits in between 83.7 and 84.1 if the addition of 1 unit of the MMR will increase by 206.691 per 100,000 live births. Regencies / cities included in the category of the percentage of visits of pregnant women at between 83.7 and 84.1 are Sampang Regency..

On the condition of pregnant women the percentage of visits in between 84.1 and 84.5 if the addition of 1 unit of the MMR will be decreased by 199.875 per 100,000 live births. Regencies / cities included in the category of the percentage of visits of pregnant women at between 84.1 and 84.5 is of Blitar City.

On the condition of the percentage of pregnant women visit a greater than 84.5 if the addition of 1 unit of the MMR will be decreased by 84.872 per 100,000 live births. Regencies / cities included in the category of the percentage of pregnant women visit greater than 84.5 are Ponorogo Regency, Trengalek Regency, Tulungagung, Regency, Blitar Regency, Kediri Regency, Malang Regency, Banyuwangi Regency, Situbondo Regency Pasuruan Regency, Sidoarjo Regency, Mojokerto, Regency, Jombang Regency, Madiun Regency, Magetan, Regency, Ngawi Regency, Bojonegoro Regency, Tuban Regency, Lamongan Regency, Gresik Regency, Pamekasan Regency, Sumenep Regency, Kediri City, Malang City, Probolinggo City, Pasuruan City, Mojokerto City, Madiun City, Surabaya City, and Batu City.

4. Assuming constant predictor variables in addition to $x_{4}$, the regression equation of a variable percentage of households receiving cash assistance and a variable percentage of households receiving cash transfers included in the nonparametric component, so that the model can be written as follows.

$$
\hat{y}= \begin{cases}2005,068-1,063 x_{4} & ; x_{4}<6,25 \\ 2328,849-52,148 x_{4} & ; 6,25 \leq x_{4}<11,78 \\ 2005,068-1,063 x_{4} & ; x_{4} \geq 11,78\end{cases}
$$

On the condition of the percentage of households receiving cash assistance in case of less than 6.25 in increments of 1 unit so MMR be down at 1,063 per 100,000 
live births. Regenciss / cities included in the category of percentage of households receiving cash transfers of less than 6.25 was Pacitan Regency, Trenggalek Regency, Tulungagung Regency, Blitar Regency, Kediri Regency, Malang Regency, Jember Regency, Banyuwangi Regency, Bondowoso Regency, Situbondo Regency, Probolinggo Regency, Pasuruan Regency, Sidoarjo Regency, Mojokerto Regency, Jombang Regency, Nganjuk Regency, Madiun Regency, Magetan Regency, Ngawi Regency, Bojonegoro Regency Tuban Regency, Gresik Regency, Bangkalan Regency, Sampang Regency, Pamekasan Regency, Sumenep Regency, Kediri City, Blitar City, Malang City, Probolinggo City, Pasuruan City, Mojokerto City, Madiun and Surabaya City, Batu City.

On the condition of the percentage of households receiving cash transfers between 6.25 and 11.78 in the event increments of 1 unit of the MMR will be decreased by 52.148 per 100,000 live births. Regencies / cities included in the category of percentage of households receiving cash transfers between 6.25 and 11.78 are Ponorogo Regency .

On the condition of the percentage of households receiving cash transfers over from 11.78 in the event increments of 1 unit of the MMR will be decreased by 1,063 per 100,000 live births. Regencies / cities included in the category of percentage of households receiving cash transfers of less than 6.25 was Lamongan Regency.

5. Assuming constant predictor variables besides $x_{5}$, then the regression equation of the variable ratio of publivhealth centers and hospitals and variable ratio of health centers and hospitals belonging to the nonparametric component, so that the model can be written as follows.

$$
\hat{y}= \begin{cases}2005,068-5,522 x_{5} & ; x_{5}<8 \\ -1019,636+372,566 x_{5} & ; 8 \leq x_{5}<8,29 \\ 7933.487-720,651 x_{5} & ; 8,29 \leq x_{5}<8,58 \\ -920,472+335,45 x_{5} & ; x_{5} \geq 8,58\end{cases}
$$

On the condition of health centers and hospitals ratio of less than 8 if the addition of 1 unit of the MMR will be decreased by 5,522 per 100,000 live births. Regencies / cities included in the category of public health centers and hospitals ratio of less than 8 are Tulungagung Regency, Blitar Regency, Kediri Regency, Malang Regency, Jember Regency, Banyuwangi Regency, Bondowoso Regency, Situbondo Regency, Probolinggo Regency, Pasuruan Regency, Sidoarjo Regency, Mojokerto Regency, Jombang Regency, Magetan Regency, Ngawi Regency, Regency. Bojonegoro Regency ,Tuban Regency, Gresik Regency, Bangkalan Regency, Sampang Regency, Pamekasan Regency, and Batu City.

On the condition of public health centers and hospitals ratio between 8 and 8.29 in case of an addition of 1 unit of the MMR will increase by 372.566 per 100,000 live births. Regencys / cities included in the category of public health centers and hospitals ratio between 8 and 8.29 are Trenggalek Regency.

On the condition of public health centers and hospitals ratios between 8.29 and 8.58 in case of an addition of 1 unit of the MMR will be decreased by 720.651 per 100,000 live births. Regencys / cities included in the category of health centers and hospitals ratios between 8.29 and 8.58 are Regency Pacitan, Malang, and Madiun.

While the Regency / city are included in the category of health centers and hospitals ratio greater than 8.29 is Nganjuk Regency, Madiun Regency, Sumenep Regency, Kediri City, Blitar City, Probolinggo City, Pasuruan City, Mojokerto City, and Surabaya City.

\section{CONCLUSION}

Maternal Mortality Rate data characteristics in East Java province reached an average of 99.86 maternal deaths per 100,000 live births. Regencies / cities with the highest maternal mortality rate is the city of Blitar, which is 236 maternal deaths per 100,000 live births, while the Regencies / cities with the lowest maternal mortality rate is the City of Madiun, which amounted to 38 maternal deaths per 100,000 live births. The best spline truncated nonparametric regression model produced by using a combination of knots, where all predictor variables significantly influence the MMR, namely the percentage of household with percentage of households with clean and healthy behavior $\left(x_{1}\right)$, the percentage of treatment of obstetric complications $\left(x_{2}\right)$, the percentage of visits of pregnant women $\left(x_{3}\right)$, The percentage of households receiving cash assistance $\left(x_{4}\right)$, and the ratio of public health centers and hospitals $\left(x_{5}\right)$. The coefficient of determination obtained by the truncated spline nonparametric regression model with a combination of knots point of 88.13 percent. Suggestions for further research is to add other alleged predictor variables that able to affect maternal mortality rate, thus the information in order to effort the decrease of maternal mortality rate will be improved.

\section{REFERENCES}

[1] Ministry-of-Health, Indonesia Health Profile, Jakarta: Ministry of Health, 2016.

[2] M. Ermalena, "SDGs Health Indicators in Indonesia.," in The 4th ICTOH, Jakarta, 2017.

[3] I. Mutfi, Modeling of Factors Affecting Total Maternal Mortality in East Java Method Using Poisson Geographically Weighted Regression, Surabaya: Indian Institute of Technology., 2018.

[4] Dedi, Syahrul and Ikacipta, Improvement of Maternal Health with Nonparametric Regression Spline On Maternal Mortality Data in Indonesia, Surabaya: Institute of Technology, 2017.

[5] Ministry-of-Health, Health Profile 2016 East Java Province, Surabaya: Ministry of Health, 2016.

[6] R. Eubank, Spline Smoothing and Nonparametric Regression, New York: Dekker Mercel, 1988.

[7] W. Hardle, Applied Nonparametric Regression, New York: Cambridge University Press, 1990.

[8] I. Budiantara, "Parametric and Nonparametric Estimation for Regression Curve Approach," in Seminar V National Statistics, Surabaya, 2001.

[9] G. Wahba, Spline Models For Observational Data, Siam, 1990.

[10] R. Mochtar, Synopsis Obstetrics (Vol.1), Jakarta: RGC, 1998. 